\title{
円盤型粒子を用いた高速せん断流れで 生じるせん断応力の特性
}

\author{
一場 勝幸 1 - 岩下 和義 $2 \cdot$ 小田 匡寛 ${ }^{3}$ \\ 1正会員 国土交通省北海道開発局（广045-0002 北海道岩内郡岩内町字東山109） \\ E-mail:katsu1ba@gmail.com \\ 2 正会員 埼玉大学准教授 大学院理工学研究科（†338-8570 埼玉県さいたま市桜区下大久保255) \\ E-mail: iwa@post.saitama-u.ac.jp \\ 3 正会員 埼玉大学教授 大学院理工学研究科（率338-8570 埼玉県さいたま市桜区下大久保255) \\ E-mail: oda@post.saitama-u.ac.jp
}

\begin{abstract}
高速でせん断変形を受ける粒状体流の物性を調べるために，平面上での運動形態が異なる2種類（円盤 と球体）の粒子を駆動する高速せん断試験を行った. 平面上で円盤はすべり, 球体はすべりと転がりを交 えて運動するという違いがあるものの, 観測されたせん断応力とひずみ速度の関係は, フラクションが低 い疎な流れではせん断応力はひずみ速度の2乗に比例し, 密な流れの場合, ひずみ速度が速い場合には2乗 に比例し，遅い場合にはこの関係から外れるという同じ傾向を示した．円盤粒子を用いる場合，実験可能 なフラクションとひずみ速度の範囲は球体粒子に比べそれぞれ限定されるが，PTVソフトウエアによる粒 子運動の追跡が容易であり速度分布を精度良く測定できることが確かめられた。
\end{abstract}

Key Words : shear flow, granular material, rapid flow, disc, particle tracking

\section{1. はじめに}

土は粒子で構成されており，そのためダイレイタンシ 一やせん断帯幅の寸法効果などが生じる. 粒子によって 構成されているものは粒状体と呼ばれ，粒状体は連続体 のように挙動したり, 流動や対流など液体的に挙動した りと, 粒子自身の特性や周囲の環境により様々な挙動を 示すことが知られている. 土質力学の範囲でも，地す心゙ り, 斜面崩壊，土粒子と水分が混じって移動する土石流， 乾燥した岩塊が外乱により流れだす岩屑流は粒状体の流 れと見なすことができる，従来，粒状体の流れの研究は 2 つの極端なケースを中心に行われてきた. 1 つめは準 静的流れ(quasi-static flow) と呼ばれる土の静的変形を含む ケースで, 粒子流に与えられるせん断ひずみ速度が遅い 場合であり, 粒子加速度の影響が無視でき, 応力は粒子 同士の継続的接触点での接触力により伝達されている.

もう1つは，粒子流のせん断ひずみ速度が速い高速流れ (rapid flow, inertia-dominant flow) と呼ばれるケースであり, 流れは気体の分子運動に似ており, 加速度や慣性の影響 が大きく応力は衝突する粒子間の運動量の交換により伝 達される.この $2 つ の$ 領域の間は, 両者が混じった領域 であり遷移領域と呼ばれている.

高速流れおよび遷移領域の流れに関しては，主にせ
ん断実験により忘力や忘力比の特性に関する研究が行わ れてきた. また粒子の運動機構に基づいて発生する応力 の特性を理解しようという研究も行われている. 高速せ ん断流れで発生する応力は粒子同士の衝突や接触により 生じるが，その大きさは粒子の自重により生じる応力よ り小さい場合もあるため, 重力の影響をなるべく排除し た実験を行う必要がある. せん断試験による応力測定は, Bagnold $^{1)}$ の実験が最初のものであるといわれている. Bagnoldは粒子を同じ密度の液体に浮遊させることで重 力の影響を消し，垂直応力のとせん断応力 $て$ 両方を測定 した.このため測定結果には間隙流体の粘性の影響が含 まれている. 実験結果として，せん断ひずみ速度が速い 場合は粒子の慣性が卓越するため発生する応力はせん断 ひずみ速度の2乗に比例する, せん断ひずみ速度が遅い 場合には液体の粘性が卓越し発生する応力はせん断ひず み速度に比例する, 応力比 $/ \sigma$ のせん断ひずみ速度およ び充填率に依存すると報告している.

Hanes \& Inman ${ }^{2}$ は間隙流体を入れない乾燥した粒子に せん断流を生じさせ応力を測定した. 上下の壁にはさま れた同心円空間に粒子を充填し，下方の壁を高速で回転 させることで粒子にせん断流れを生じさせた. 下壁の速 度が遅いと粒子はせん断流れを生じないため, 実験可能 なせん断ながれはひずみ速度が5000 (\%/sec)以上の速い流 
れに限られる.また，フラクション (粒子充填率) が低 い疎な流れは，重力が作用のために疎な状態を維持でき ないため, 実験可能な流れはフラクションが高い密な場 合に限られる. 測定の結果, せん断ひずみ速度が速い場 合には垂直応力とせん断応力ともせん断ひずみ速度の2 乗に比例すると報告している.

理論的研究として, Savage \& Jeffrey ${ }^{8}$ は弾性粒子同士 が2粒子間衝突する際に運動量交換を行うことで応力が 発生すると仮定して応力の理論式を導き，応力はひずみ 速度の 2 乗に比例することを示した. 本仮定は中程度の フラクションの場合のみに有効で，それ以外の場合には 成り立たないと説明している，この理由として，フラク ションが高いと2粒子衝突ではなく多粒子間衝突および 持続する粒子間接触が主体になることと, フラクション が低い場合には粒子は衝突せずに直接境界まで移動して 運動量を伝達するため2粒子間衝突の仮定が成り立たな いことをあげている.

せん断中の粒子運動を観察する研究も行われている. Drake $^{\text {の) }}$ は斜面上を流れる粒子流の垂直断面を高速度ビデ オカメラで計測し，各部の流れをフラクションと接触状 況に応じて分類した. Hanes \& Inmanは高速せん断装置の 壁を透明にすることで流れの表面にある粒子の運動を観 察した. Hsiau \& Yang ${ }^{3)}$ は同様なせん断装置で収録した動 画像にPTV(Particle Tracking Velocimetry)を適用し，個々の 粒子の移動軌跡, 粒子速度と粒状体温度（Granular Temperature）の分布を観測している. Blair \& Kudrolli” PTVで得られる粒子の移動軌跡上り粒子の接触状況を調 べる方法を提案している.

岩下ら お および一場ら゙ は, 応力測定と粒子運動を追 跡することを目標として，平面上に置いた2枚の円形の 壁にはさまれた同心円領域をせん断セルとする高速せん 断装置を提案し，セル内に1層に敷き詰めた球体粒子を 駆動する実験を行った．本装置は，粒子の平面内での運 動には重力の影響が底面との摩擦以外には入らない, 間 隙流体の浮力を用いないため粘性の影響は入らない, 全 粒子の運動を直接観察可能, 流れで生じるせん断と垂直 応力を同時に測定することができるという特徵を持つ.

測定の結果, 応力はせん断と垂直の両成分ともフラクシ ヨンが低い（0.1程度以下）疎な流れではひずみ速度の ほぼ 1 乗に比例し, 中程度（0.7程度）以上のフラクシ ヨンではひずみ速度が速い場合はひずみ速度の2乗に比 例し，ひずみ速度が低くなると応力はひずみ速度の2乗 に比例する関係から外れると報告している，また高速度 ビデオ画像を肉眼で観察し, フラクションを増や寸につ れ粒子衝突の主体が2体衝突から多体衝突に変化し，そ れに応じて応力とひずみ速度の関係が変化していくこと, 高いフラクションでひずみ速度が低い場合には粒子がセ
ルの両方の壁をつなぐように連なる柱状構造が形成され ることを報告し, 粒子間の接触が応力のひずみ速度依存 性に影響を与えていると指摘している.

これらの実験では以下の3つの問題点が指摘されてい る. 球体粒子は他粒子との衝突後, 床面上を滑った後に 転がりに移行するため, すべりと転がりを定量的に測定 することが困難である. 並進運動2成分の変位は測定で きるが, 回転運動3成分は測定と思われるので, 運動量 や運動エネルギーの伝達等を追跡することが困難である. 粒子一層の流れとするためせん断セルの天板と床面で粒 子をはさんでいるためどちらかの面と摩擦を生じている.

このような球体粒子に対し, 円盤形状の粒子は床面 を滑って移動するため転がり摩擦よりずっと大きなす心゙ り摩擦が生じるという久点を持つが, 原理的に並進2成 分と面内回転1成分の 3 自由度の変位を測定できる, 動画 像処理により運動を追跡しやすい，同じ厚さであれば直 径の異なる円艋粒子を混在できる, という長所を持つ. 本研究は, 平面2次元せん断装置により低摩擦素材製の 円盤粒子を用いてせん断試験を行い，円盤粒子の場合の せん断応力の示すフラクション依存性とひずみ速度依存 性を調べ, 動画像処理PTVを適用することで粒子速度を 定量的により精度良く測定することを試みたものである.

\section{2. 実験方法}

\section{(1) 実験装置概要}

本研究で用いる実験装置の概要を図-1に示寸. 水平で 平らなステンレス製の床板上に置いた円形の鋼製外壁と 内壁に囲まれる同心円部分をせん断七ルとする. ステン レス製床板は固定されており, 内壁は速度可変のモータ 一により回転し，せん断セル内に配置した粒子に流れを 生じさせる，外壁と床の間には摩擦を軽減するために心゙ アリングを設置してあり, 粒状体の流れが外壁を回転さ せようとする力, せん断力を計測するためのロードセル を外壁と床面との間に設置している. 内・外壁の粒子と 接触する側には，壁と粒子の動きを同調させるために粒 子と同じ直径の半円柱形の突起を粒子直径分の間隔を空

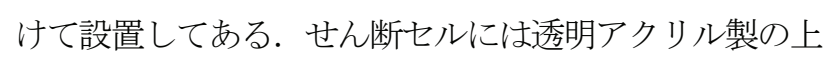
蓋をかぶせてあり，全ての粒子の運動を観察できる.上 蓋は内壁に固定され内壁とともに回転し, 実験は等体積 せん断試験となっている.

せん断セル内のせん断ひずみ速度の平均值 $\dot{\gamma}(1 / \mathrm{sec})$ は, 回転による内壁の縁の接線方向速度 $U$ とせん断セル幅 $H$ より, 以下の式(1)で定義する.

$$
\dot{\gamma}=\frac{U}{H}
$$




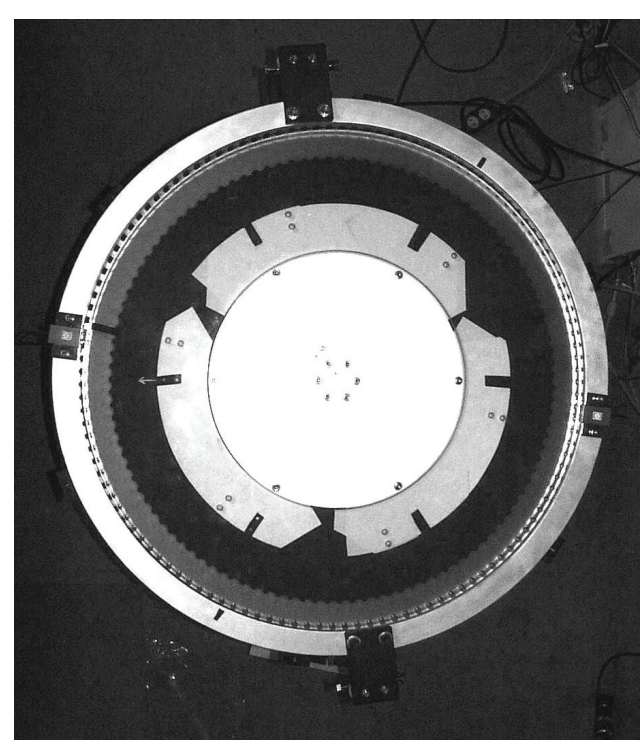

(a)

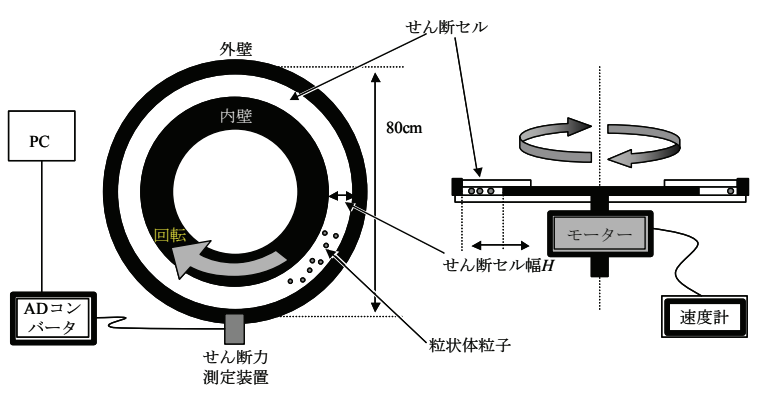

(b)

図-1 装置概要 (a)：上方からみた実験装置，(b) : 装置概念 四

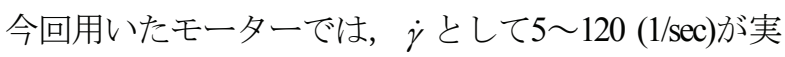
験可能であるが，モーターおよびモーターのギアを交換 することでせん断ひずみ速度の範囲を変えることができ る.

\section{(2) 応力の測定方法}

本実験装置は，粒子流れにより外壁をまわそうとする せん断応力と体積彭張させようとする垂直応力を同時に 測定することを目標に設計された。しかし実験の結果 ${ }^{5}$, 両応力を同時に測定すると外壁は微小に回転するのと同 時にふくらみを受け，特に応力が大きい場合には外壁の 回転中心が装置中心から少しずれてしまうことが判明し た. 内壁の中心は装置中心となっているため, 内壁と外

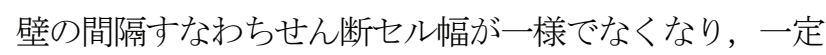
としたいひずみ速度が装置内で変動してしまう。より正 確に測定するためには垂直応力を測る実験とせん断応力 を測る実験をせん断セルの支持条件を変えて別々に行う
必要があると思われる，特に垂直応力に関しては，精度 よく測定するためには実験装置を大幅に改良する必要が ある. 球体を用いた実験)ではせん断と垂直応力の示す ひずみ速度依存性は定性的に同様であったため，今回は せん断応力の示すひずみ依存性を調べることに目的を限 定し，セル幅が均一になるよう外壁は回転のみ許される ようにベアリングで固定した. 垂直応力を計測しないた め, 工学的に重要な応力比に関しては議論することがで きない.

粒子流れが外壁を回転させようとする力 $T$ は，外壁 と固定床との間に設置したせん断用ロードセル（図1 (b) 参照, 対称な位置に2つ設置) の測定值 $T_{1}, T_{2}$ の合 計として測定される. せん断応力 $\tau_{x y}$ は $T$ を外壁の面積 で除することで求まる.

$$
\tau_{x y}=\frac{T}{t \cdot 2 \pi r_{\text {out }}}=\frac{T_{1}+T_{2}}{t \cdot 2 \pi r_{\text {out }}}
$$

ここで， $r_{\text {out }}$ を実験装置の外壁半径， $t$ をせん断セル の深さ（三粒子の厚さ）とする. 式(2)によりせん断応 力の瞬間值が求まるが，応力は外壁へ粒子が衝突する衝 撃の合計であるため，時間的に細かな変動が大きい.こ のため本研究ではサンプリングレート 0.02 秒で 120 秒以上 計測した $\tau_{x y}$ の平均值を平均応力 $\bar{\tau}_{x y}$ として用いる.

平均応力 $\bar{\tau}_{x y}$ は, 実験に用いた粒状材料の寸法や素材 密度，作用させたひずみ速度の影響を受けるため，異な る実験装置・実験条件によるデータと直接比較すること は不適当である.このため本研究では，粒子が1対1で接 触（binary collision）すると仮定した衝突理論に基づいた 無次元化応力 $\tau_{x y}^{* 2}$ を用いる.

$$
\tau_{x y}^{*}=\frac{\bar{\tau}_{x y}}{\rho_{p} D^{2} \dot{\gamma}^{2}}
$$

ここで， $\rho_{p}$ は粒子素材の密度， $D$ は粒子直径とする。 本研究では粒子形状の違いを考慮せずに球体粒子と円盤 粒子の両方で無次元化に同じ式を用いることとする.

粒子の充填率であるフラクション $v$ に，いろいろな 定義があるが，粒子の総投影面積とせん断セル面積との 比である面積フラクション $v_{2}$ と, 粒子の総体積とせん 断セル体積との比である体積フラクション $v_{3}$ がよく用 いられている. 本研究では面積フラクションを用いるこ ととし，既往の実験データと比較する際に実験装置ごと の差を考慮するため，それぞれの $v$ より正規化フラクシ ヨン $v^{*}$ を求めて用いることにする.

$$
v^{*}=\frac{v}{v_{\max }}
$$

ここで $v_{\max }$ は実験装置ごとの最大可能フラクションと する. 装置に粒子を可能な限り詰め込むと $v^{*}$ は 1.0 とな る.

実験装置の外壁半径 $r_{\text {out }}$ は40cmで固定であるが，内壁 


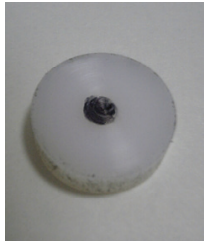

(a)

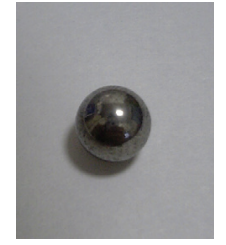

(b) 図-2＼cjkstart実験で使用したモデル粒子 (a)ポリエチレンディスク，(b)スチールボール

表-1 粒子模型の物性

\begin{tabular}{|l|l|l|}
\hline 粒子 & $\begin{array}{l}\text { ポリエチレンデ } \\
\text { イスク }\end{array}$ & スチールボール \\
\hline 形状 & 円盤 & 球体 \\
\hline 直径 $D(\mathrm{~mm})$ & 23 & 10 \\
\hline 厚さ $t_{c}(\mathrm{~mm})$ & 6 & $(10)$ \\
\hline 質量 $(\mathrm{g})$ & 2.31 & 4.08 \\
\hline $\begin{array}{l}\text { 見かけの密度 } \\
\rho_{p}(\mathrm{~g} / \mathrm{cm} 3)\end{array}$ & 0.93 & 7.79 \\
\hline 反発係数 $e$ & 0.87 & 0.90 \\
\hline $\begin{array}{l}\text { 同じ粒子同士での } \\
\text { すべり摩擦係数 }\end{array}$ & 0.23 & 0.25 \\
\hline $\begin{array}{l}\text { 床面との見かけの } \\
\text { 動摩擦係数 } \mu\end{array}$ & 0.25 & 0.14 以下 \\
\hline
\end{tabular}

半径 $r_{i n}$ とせん断セル幅 $H=r_{\text {out }}-r_{i n}$ は，粒子を流寸際 にひずみ速度分布がセル内でなるべく一様になるように 設定した．セル幅を粒子直径の数倍以下に狭くすればセ ル内の粒子速度はある程度一様な勾配を示寸が，セル幅 を広げると，内壁付近の粒子のみが流動し外壁付近の粒 子は六方最密充填配置の結晶構造を形成しほぼ停止して しまうため，流動領域と結晶化した領域の境界にひずみ の局所化が生じ，セル内のひずみ速度分布は非一様にな る. 本研究ではこの問題を避けるために粒子直径の約 5 倍のセル幅という条件を採用し， $r_{i n}=30 \mathrm{~cm}, H=10 \mathrm{~cm}$ とした．以降のデータ処理ではせん断セル内でのひずみ 速度 $\dot{\gamma}$ は一様であるとみなし, 式(1)で求めることとする.

\section{(3) 実験に用いる粒子}

本実験装置では，流動させる粒子として，球体と円盤 の形状の両方を用いることができる. 球体粒子の場合, ステンレス製床面との間での転がり抵抗はすべり抵抗に 比べて小さいため，粒子が転がって移動する場合には見 かけの摩擦係数を極めて小さくすることができる4)。こ れに対し今回用いる円盤形状粒子は床面上をすべりで移 動するため，なるべく床面上でのすべり摩擦が小さい材 質を選ぶ必要がある。摩擦が大きいと運動エネルギーが 摩擦で消耗され, せん断流れが継続しない恐れがある.

本研究では低摩擦ポリエチレン素材（商品名ニューラ イト）製の円盤粒子を用いた．図-2に写真を，表-1に物
性を示す．円盤の直径 $D$ は $23 \mathrm{~mm}$ で上下面は平ら，厚み は6mmとなっている. 摩擦係数は粒子を床面上で滑らせ て計測した，比較のために示した鋼鉄製ボールの摩擦係 数り けの值となっている. 反発係数 $e$ は，2つの粒子を衝突 させ，速度変化より求めた。

計測の結果, 円盤粒子と床面との摩擦係数は 0.25 と期 待したほど小さくなかったため, 実験可能なひずみ速度 の範囲は球体粒子に比べて狭く, ひずみ速度が低い範囲 でせん断流れが持続しなかった．またせん断七ル内の粒 子数が少ない $\left(v^{*}<0.5\right.$ 程度 $)$ 場合もせん断流れは継続しな かった. この理由は, 粒子が衝突後に別の粒子と衝突す るまでの自由移動距離が長く床面との摩擦で粒子が止ま ってしまうためと思われる，予備実験として，床面を同 じ低摩擦ポリエチレン素材にしてみたが，スチール製の 床よりも摩擦が大きくなるという結果であった.

\section{(4)粒子運動の測定}

本実験装置では，透明アクリル製の上蓋を通して，全 ての粒子の動きを見ることができる，画像収録には，高 速度ビデオカメラ(Fastcam-X 1280PCI, 毎秒1000フレーム, 画像サイズ1280×256 ピクセル，モノクロ)を用い，粒子 追跡解析にはPTVソフトウエアであるDIPP-Motion 2Dを 用いた.このソフトウエアは画像のパターンマッチング を行うことで画像の移動を追尾する. 用いたポリエチレ ン素材は白色で床面とのコントラストが明確なため, そ のままでも粒子追跡を行えるが，追跡精度を向上させる ため粒子上面中央に黒色の小さな円形マーク（図2(a)）を描き，それを追跡した. 粒子追跡ソフトにより このマークの時々刻々の位置座標を読み, 位置の変化か ら瞬間の粒子速度を求めた。 せん断セル全体を収録する と画像のピクセル数が不足して精度が悪くなるので, せ ん断セルの一部のみを撮影した. 実験開始後20秒程度で 応力がほぼ一定值に落ち着くことから流れは定常状態に 達すると判断し， 20 秒以降に速度と応力を計測した. な お粒子の速度は瞬間的に大きく変動するので，4秒分計 測した平均值を平均粒子速度とした。

\section{3. 測定結果}

\section{(1) せん断応力時系列波形}

図-3にポリエチレンディスクを利用した実験でのせん 断セル内の状況，図-4に対応するせん断応力の時刻暦波 形の一例を示寸．図-4では，波形の変動を見るためにせ ん断応力 $\tau_{x y}$ を各ケースの平均応力 $\bar{\tau}_{x y}$ で正規化した值 を縦軸にしている. 


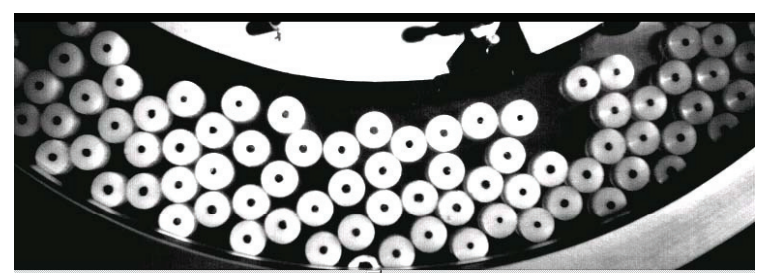

図-3 せん断試験中の粒子配置例 $\left(v^{*}=0.80 \quad \dot{\gamma}=25.04\right.$ の場 合，各ポリエチレンディスク中心のマークは追跡用マ ークとなっている)

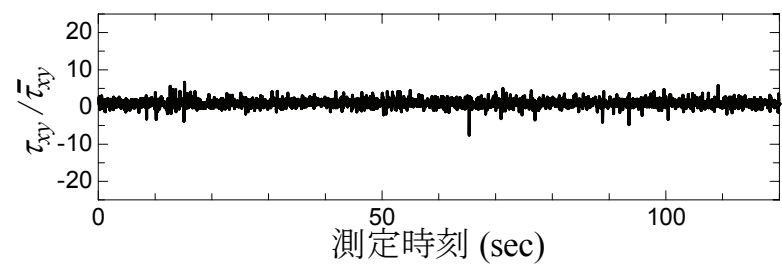

(a) $v^{*}=0.60, \dot{\gamma}=34.7$

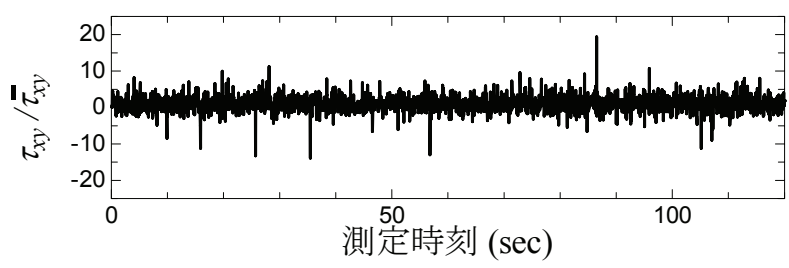

(b) $v^{*}=0.80, \dot{\gamma}=25.0$

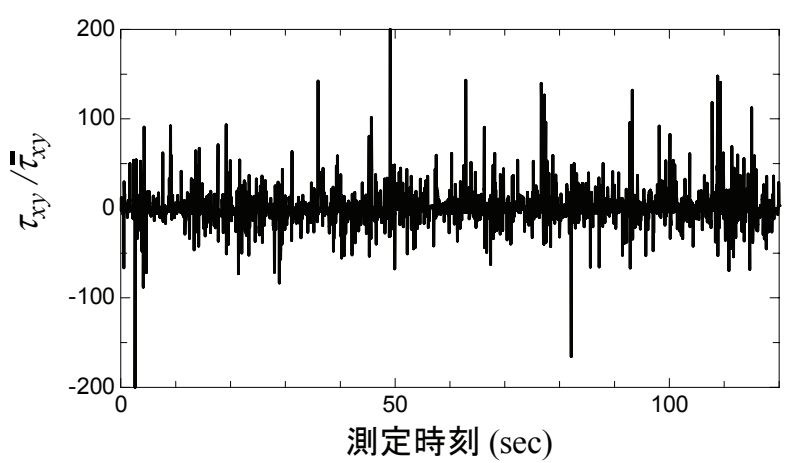

(c) $v^{*}=0.85, \dot{\gamma}=8.18$

図-4 せん断応力の時間的変動（ポリエチレンディスクの場 合, 縦軸のせん断応力 $\tau_{x y}$ はそれぞれの時間平均值 $\bar{\tau}_{x y}$ で正規化してある)

床面との摩擦が大きかったので， $v^{*}<0.5$ 領域では せん断流れを継続させることができなかった。図-4(a) は実験した範囲で最も疎な $v^{*}=0.600$ 場合であるが，せ ん断応力の波形には大きな振動がなく平均值の周辺に落 ち着いている.これは外壁へ粒子が頻繁に衝突するため,
変動が少なくなったものと考えられる. 負のせん断応力 も測定されているのは，外壁とつながったロードセルが 質点とバネからなる 1 自由度振動系として減衰振動した ためと考えられる. 試しに外壁に瞬間的な打撃を 1 回の み与えたところ, 測定されたせん断応力は減衰振動の形 状で正と負の応力が交互に生じるものであった．粒子衝 突の衝撃のたびにロードセルが振動している可能性があ る. これ以外にせん断方向と逆向きの衝突や接触により 負のせん断応力が発生する可能性もあるが，高速度ビデ 才画像ではそのような衝突はほとんど見られなかった. 全ての測定結果において, 平均応力 $\bar{\tau}_{x y}$ は正の值となっ ており，本研究では平均応力を評価に用いることにする. この $v^{*}=0.60$ においては，ひずみ速度 $\dot{\gamma}$ の值によらず 波形は平均值周辺で小さく振動する波形であったが,

図-4(b)，(c) と $v^{*}$ を高くするのに従い，波形に大きな スパイク状の変動が見られるようになる.この傾向は $v^{*}$ が高くなるにつれまたひずみ速度 $\dot{\gamma}$ が低くなるに明 瞭に現れるようになる. 応力がスパイク状に変動する際 には，粒子同士が激しくきしりあう音が観測され，ビデ 才画像により内壁と外壁との間に粒子が連なる柱構造の 形成が確認されることより，柱構造の形成がスパイク状 応力が発生する原因であると思われる. 形成された柱構 造は強度が高いため, 大きなせん断応力が回転への抵抗 として測定されたものと思われる. またせん断を持続さ せるためには柱構造を破壊するだけの十分なトルクを与 える必要があるが，用いたモーターの容量が十分でなか ったために内壁の回転速度が低下し，ひずみ速度が低下 してしまうことで柱構造がより形成されやすくなり，大 きなせん断応力が測定された可能性もある.これらの観 察された波形が示す傾向はスチールボールでの傾向と定 性的に一致する.

\section{(2) 粒子速度の分布}

図-5にPTVソフトで求めた $100 フ レ ー ム （ 0.1$ 秒）分の 粒子移動軌跡，すなわち図-3で粒子中央に付けたマーク の移動軌跡を示す. 図-5 (a) は $v^{*}=0.50$ の場合で, 図一 5 (b) は $v^{*}=0.80$ の密な場合となっている. 図-5(a)の場合, 駆動された内壁に近い粒子は速く外壁近くの粒子はゆっ くりとせん断を受けおり, セル内の全領域で流れている ことがわかる．また流れがそれほど密でないために粒子 軌跡の折れ曲がる点が少なく衝突頻度が高くないことと， 流れと直角方向の移動量が大きく, 内壁から外壁近傍ま で他の粒子と衝突することなく移動している粒子もある ことが読み取れる。図-5(b)では，セル内の外壁に近い 半分の領域の粒子は停留に近い状態とはいえ振動しなが らゆっくりと流れていることと, 内壁に近い領域ではか なり速い速度で流れており，七ル内でひずみ速度がかな 
り異なることと，良く流れる領域とゆっくりと流れる領 域との間でひずみ速度の段差があることがわかる。また， 粒子の密度が高いために粒子間の衝突頻度が高く, 粒子 の流れと直角方向の移動量は小さいことも読み取れる.

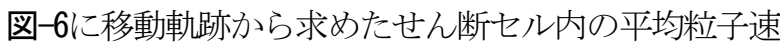
度（せん断方向成分）の分布を示す. 図の (a) は $v^{*}=0.60$ の場合, 図( $(b)$ は $v^{*}=0.85$ の密な場合となっている。横軸 は粒子中心の外壁からの距離 $d$ をせん断セル幅 $H$ で割 った值であり,$d / H=0$ が外壁の,$d / H=1$ が内壁の位 置を示す. 縦軸は粒子の流れ方向の平均速度 $u_{s}$ を実験 時の内壁の接線方向速度 $U$ で正規化している. 粒子速 度はばらつきが大きいため，せん断セル内を外壁からの 距離に応じて14領域に分割し，隣り合う2領域ごとに平 均した值を示した．図には，セル内の速度分布が外壁か らの距離に比例しひずみ速度が一様となる場合を表す実 線と, 粒子速度が外壁からの距離の2乗に比例する場合 を表す破線を示してある.

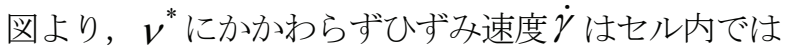
一様でないことと, 内壁の速度と内壁沿いの粒子との間 ですべりが生じていることがわかる．図-6(b)に示すよ うに $v^{*}$ が0.7を超えると内壁と粒子間のすべりは減る.

$\dot{\gamma}$ が減少するのに従い内壁と粒子との間のすべりが大 きくなる傾向が見られる. どの測定ケースでも，粒子速 度は外壁からの距離の2乗に比例している.この傾向は Hsiau \& Yang ${ }^{3}$ も報告している. 岩下ら ${ }^{4} は$ ，同じ高速せ 儿断装置でスチールボールを用いた実験で, 高速度ビデ 才画像から手作業で粒子速度を測定した結果，セル内の ひずみ速度の分布はほぼ一様であると報告している．今 回のひずみ速度が一様でない理由は，用いた粒子の摩擦 が大きく移動中に運動エネルギーを失い，また反発係数 が小さいために他粒子との衝突時に運動エネルギーを失 うため, 速度の減衰が激しく現れたためかもしれないが, 詳しくは不明である.

本研究では, セル内のひずみ速度文として式(1)を用 いることとするが，内壁と粒子との間のすべりを評価し ていないため, 式(1)は実際に作用するひずみ速度より 大きめの值を与えると思われる.

\section{(3)ひずみ速度の影響}

図一にたホリエチレンディスクでのひずみ速度 $\dot{\gamma}$ と平均 せん断応力 $\bar{\tau}_{x y}$ の関係を示寸. 各測定值を最小二乗法で 近似した曲線も記入してある。 $\bar{\tau}_{x y}$ はフラクションの増 加に伴い増加することと, どのフラクションでもひずみ 速度の増加に従い増加していることがわかる.

図-8にひずみ速度 $\dot{\gamma}$ と無次元化応力 $\tau_{x y}^{*}$ との関係を示 す. 図-8(a)にポリエチレンディスクでの測定值を図8(b)にスチールボールでの測定值 ${ }^{4}$ を示す，図で右下が

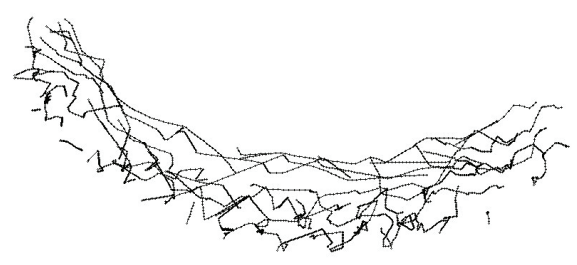

(a) $v^{*}=0.50, \quad \dot{\gamma}=34.6$ の場合

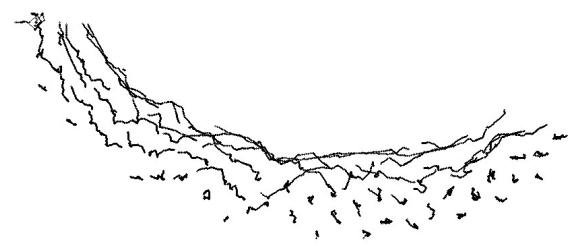

(a) $v^{*}=0.80, \quad \dot{\gamma}=14.8$ の場合

図-5 せん断セル内での粒子移動軌跡(100フレーム分)

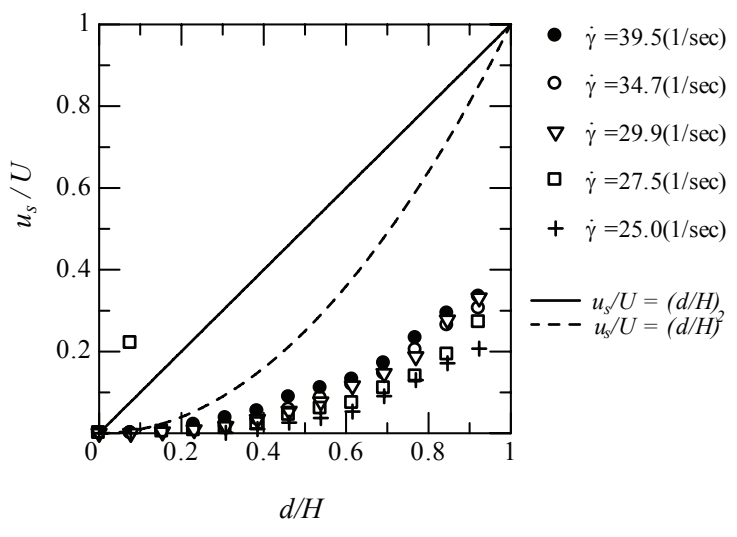

(a) $v^{*}=0.60$ の場合

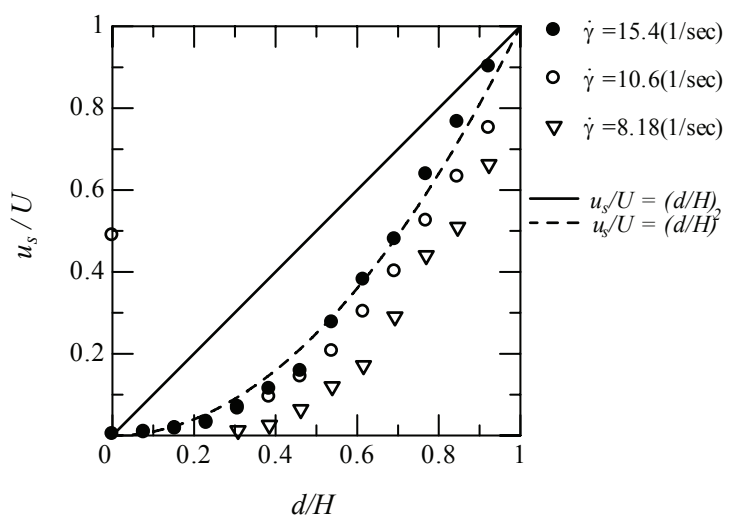

(b) $v^{*}=0.85$ の場合

図-6 せん断セル内での粒子速度分布（せん断方向成分） 
りの実線は平均応力 $\bar{\tau}_{x y}$ が $\dot{\gamma}$ の3乗に, 水平線は2乗に, 右下がりの破線は1乗に比例する傾きを表す。図の丸印 は，柱構造の形成が確認されたデータを示す。この図で ポリエチレンディスクの方がスチールボールに比べて $\tau_{x y}^{*}$ の值はばらついている. ポリエチレンディスクで $v^{*}$ が最も小さい 0.50 のデータは，床との摩擦の影響が大 きかったせいか壮らついており一定の傾向を示していな い. スチールボールでのセル内に粒子が少ない $v^{*}<0.2$ の場合， $\bar{\tau}_{x y}$ はひずみ速度のほぼ1乗に比例しているが， ポリエチレンディスクの場合には相当する領域は実験不 可能であった．疎な流れの場合，粒子が途中で他の粒子 と衝突することなく直接外壁まで到達し運動量を伝達す ると仮定すれば発生する応力がひず夕速度の1乗に比例 すると説明されている．スチールボールの場合は $0.2<$ $v^{*}<0.74$ 程度の範囲, ポリエチレンディスクの場合 $v^{*}$ $<0.80$ の範囲では， $\bar{\tau}_{x y}$ は $\dot{\gamma}$ の2乗に比例している.より $v^{*}$ が高い範囲，スチールボールでの $v^{*}=0.86$, ポリエ

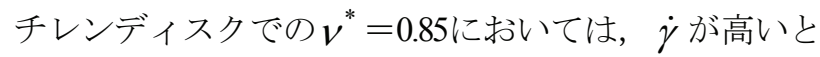
$\bar{\tau}_{x y}$ が $\dot{\gamma}$ のほぼ2乗に比例しているが， $\dot{\gamma}$ が低くなるの に従いばらつきが大きくなり2乗の傾向から外れている ように見える。柱構造の確認された丸印のデータは2乗 の傾向から外れており, 柱構造が形成されると $\bar{\tau}_{x y}$ が $\dot{\gamma}$ の2乗に比例する関係から外れると判断できる. これ以 上 $v^{*}$ が高いケースはモータの容量不足のため実験を行 うことができなかった. 以上のように，せん断応力の示 すひずみ速度依存性は6自由度で移動する鉄球でも面内 の3自由度のみで移動するディスクでも，定性的には同 じであるといえる.

\section{(4)フラクションの影響}

図-9に無次元化応力のせん断成分 $\tau_{x y}^{*}$ と正規化フラク ション $v^{*}$ の関係を示す. 比較のためBagnold ${ }^{1)}$, Hanes \& Inman $^{2)}$ ， スチールボールの結果 ${ }^{4) 5}$ も示す. どの実験結 果も $v^{*}$ が小さい範囲では， $\tau_{x y}^{*}$ は小さな值を示し， $v^{*}$ が0.5から0.6のあたりを過ぎると $\tau_{x y}^{*}$ が大きく増加すると いう点で一致した傾向を示している.ただしポリエチレ ンディスクの場合， $\tau_{x y}^{*}$ が立ち上がる $v^{*}$ は低めであり， 全体的に $\tau_{x y}^{*}$ の值が大きめとなっている，立ち上がりが 早いことを除くと， $\tau_{x y}^{*}$ と $v^{*}$ の関係は他の結果とほぼ 一致している. 応力の伝達機構が粒子が1対1で接触する 際の運動量交換である場合，応力がひずみ速度の 2 乗に 比例する関係が導かれる. 図-9でフラクションが中程度 までは $\tau_{x y}^{*}$ がばらつかないことより，この範囲ではこの 仮定がほぼ成り立っているものと思われる。 $v^{*}$ が大き くなると $\tau_{x y}^{*}$ が増大することは, 図-8において $\tau_{x y}^{*}$ と $\dot{\gamma}$ の関係が2乗に比例する関係から外れることと一致して いる.フラクションが増え粒子密度が増えた場合には,

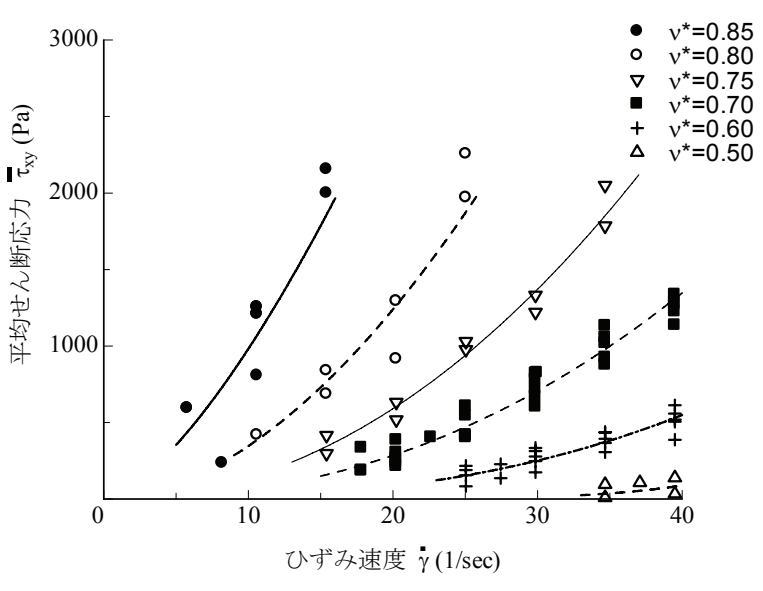

図-7 ひずみ速度 $\dot{\gamma}$ と平均せん断応力 $\bar{\tau}_{x y}$ の関係 (ポリエチレンディスクの場合)
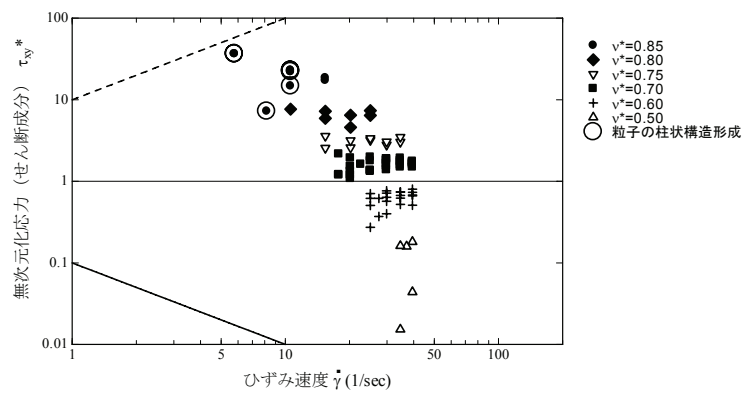

(a)ポリエチレンディスクの場合

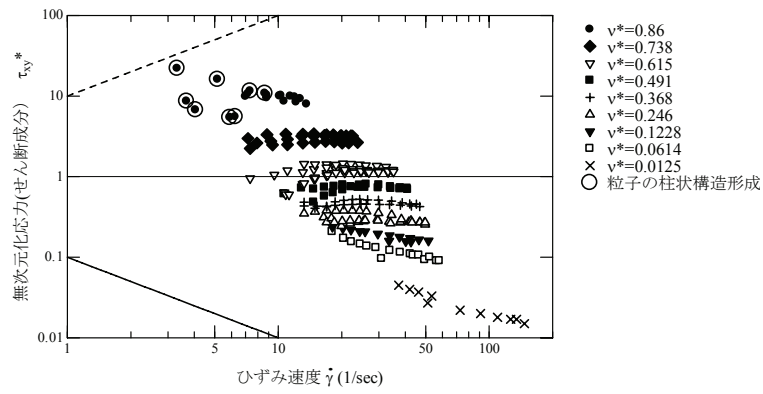

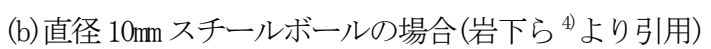

図-8 ひずみ速度 $\dot{\gamma}$ と無次元化応力（せん断成分） $\tau_{x y}^{*}$ の 関係（右下がりの実線は $\bar{\tau}_{x y}$ が $\dot{\gamma} の 3$ 乗に，水平線 は 2 乗に，破線は 1 乗に比例する傾きを表す。○を つけたケースでは，粒子が外壁と内壁をつなぐ柱状 構造の形成が確認された）

粒子群が同時に複数と接触する multiple collisionでの運動 量交換もしくは持続する粒子接触点を介しての接触力で 伝達される形態へと, 応力の発生機構が変化するために, 無次元化応力がばらつくものと思われる. 


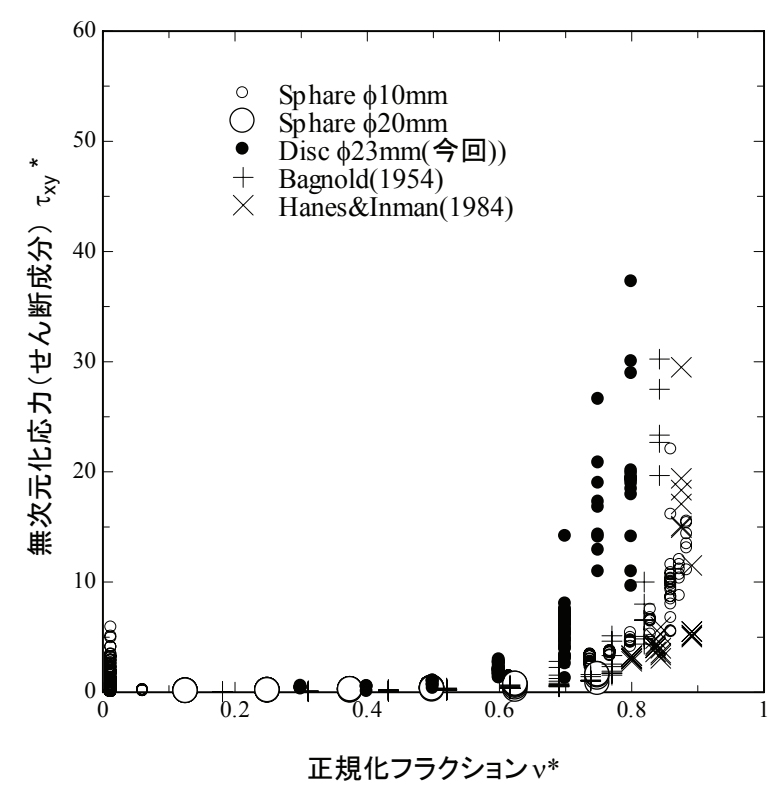

図-9 無次元化応力 $\tau_{x y}^{*}$ と正規化フラクション $v^{*}$ の関係

\section{(5)実験に用いる粒子の特性}

粒子速度測定において，ポリエチレンディスクはスチ 一ルボールに比べて高速度カメラでの粒子追跡がはるか に容易であることが判明した．スチールボールでは外部 の照明が粒子表面に反射する小さな光の点を追跡するの に対し，ポリエチレンディスクでは円盤粒子の上側表面 の円形を追跡することができるため, 粒子追跡がより容 易である. さらに，円盤の中央にコントラストのはっき りしたマークを描画し，それを追跡にすることでより追 跡の精度を高くすることができる. これよりPTVなどの 動画像処理を行う場合には，円盤粒子がはるかに適して いると思われる.

高速せん断試験に用いる際のスチールボールとポリエ チレンディスクの特徴をまとめると以下のようになる. スチールボールは見掛けの摩擦が小さくエネルギー消散 が少ないため，フラクションの低い場合やひずみ速度が 低い場合でも持続したせん断流れを再現することができ る.しかし，粒子運動は床面上でのすべりと転がりの2 形態が混じった擬似的な2次元運動となる. 粒子運動の 計測は並進運動のみ可能であるが精度はあまり高くなく， すべりところがりを明確に分離することはできない.こ のため流れの内部での運動エネルギーや運動量の把握が 困難という久点を持つ.一方，低摩擦円盤粒子は，摩擦 が大きいためフラクションの低い場合やひずみ速度が低 い場合に実験が不可能という大きな欠点を持つ.またせ ん断セル内でのひずみ速度の分布も非一様となってしま う。しかし粒子運動の測定は容易かつ精度が高いという 長所を持つ.

\section{4. まとめ}

高速でせん断変形を受ける粒状体粒子流の物性を調べ るために，低摩擦材質の円盤形状粒子を用いた高速せん 断試験を行いせん断応力を測定した. 同時に動画像処理 により粒子運動を定量的に測定することを試みた. 以前 のスチールボールでの結果と比較し，移動形態の違いが 応力一ひずみ速度関係および応力一充填率（フラクショ ン）関係にどのような影響を与えるのかを調べた。

実験の結果，低摩擦材質でもすべり摩擦が大きいため 実験可能なフラクションとひずみ速度の範囲が限定され ることが判明した. 動画像処理により粒子速度を計測し， 駆動する内壁と粒子の間にすべりが生じていることと, セル内でのひずみ速度分布が非一様性であること, 粒子 運動の追跡性に関しては円盤形状のポリエチレンディス クの方が優れていることが判明した．応力のひずみ速度 依存性に関しては，円盤粒子とスチールボールとで定性 的に同じ傾向を示すことが判明した.すなわち，フラク ションがあまり高くない範囲では発生するせん断応力は 与えるひずみ速度の2乗に比例し，フラクションが高い 範囲でひずみ速度が速い場合には2乗に比例するが，ひ ずみ速度が低い場合にはひずみ速度の2乗に比例する関 係から外れるという傾向も一致した．2乗関係から外れ る場合には，粒子がせん断セル内で連なる柱状構造が形 成されていることも確認された. 今後, それぞれの長 所・短所を生かして高速せん断試験を行うことができる と思われる.

謝辞 : 埼玉大学工学部卒の前川敦氏には，卒業研究の一 環として実験の一部を担当して頂きました．またこの研 究の一部は独立行政法人原子力安全基盤機構の原子力安 全基盤調査提案公募研究の一環として実施されました. ここに記して感謝の意を表します.

\section{参考文献}

1) Bagnold, R. A. : Experiments on a gravity-free dispersion of large solid spheres in a Newtonian fluid under shear, Proc. of Royal Society of London A, Vol. 225, pp. 49-63, 1954.

2) Hanes, D. M. and Inman, D. L. : Observations of rapidly flowing granular-fluid materials, J. Fluid Mech., Vol. 150, pp. 357-380, 1985.

3) Hsiau, S. S. and Yang, W. : Transport property measurements in sheared granular flows, Chemical Engineering Science, Vol. 60, pp. 187-199, 2005.

4) 岩下和義, 一場勝幸, 小田匡寛 : 高速せん断試験装 置による粒状体の流動特性の研究, 土木学会論文集, No.764/ III-67, pp. 147-156, 2004.

5) 一場勝幸, 岩下和義, 小田匡寛 : 高速せん断試験装 置による粒状体に生じる応力の測定, 応用力学論文 集, Vol.7, pp. 805-812, 2004. 
6) Drake, T. G. : Structural features in granular flows, J. of Geophysical Research, Vol. 95, B6, pp.8681-8696, 1991.

7) Blair, D. and Kudrolli, A. : Collision statistics of driven granular materials, Physical Review E, Vol. 67, No. 041301, pp. 1-12, 2003.

8) Savage, S. B. and Jeffrey, J. D. : The stress tensor in a granular flow at high stress rates, J. Fluid Mech., Vol. 110, pp. 255-272, 1981.
9) Jenkins, J. T. and Savage, S. B. : A theory for the rapid flow of identical, smooth, nearly elastic spherical particles, J. Fluid Mech., Vol. 130, pp. 197-202, 1983.

10) Elliott, K. E., Ahmadi, G. and Kvasnak, W. : Couette flows of a granular monolayer - an experimental study, J. NonNewtonian Fluid Mech., Vol. 74, pp. 89-111, 1998.

\section{RESEARCH OF SHEAR STRESS GENERATION IN DISC PARTICLE SHEAR FLOW BY TWO-DIMENSIONAL RAPID FLOW APPARATUS}

(2006. 12. 5 受付)

\section{Katsuyuki ICHIBA, Kazuyoshi IWASHITA and Masanobu ODA}

To study the micro-mechanics of granular flows, disc flow are generated by using two-dimensional rapid flow apparatus and shear stress and particle movement are measured. To decrease the friction between disc and floor, which disturbs particle moving, polyethylene disc instead of steel sphere are selected. By using disc particles and the rapid shear apparatus, (a) effect of solid fraction on shear stress generation, (b) effect of shear strain rate on the stress generation and (c) distribution of particle velocity are studied. It can be said that the relationship between shear strain rate and shear stress measured in disc flow is qualitatively similar to the relationship measured by using steel sphere and same apparatus. In comparison between disc and sphere, it can be said that disc has an advantage in tracking particle movement by PTV software. 